\title{
ELIZABETH SHEEHY, DEFENDING BATTERED WOMEN ON TRIAL: LESSONS FROM THE TRANSCRIPTS (Vancouver, University of British Columbia Press. 2014)
}

\section{Katrin Roots*}

In Defending Battered Women on Trial: Lessons from the Transcripts, Elizabeth Sheehy offers a critical review of legal cases involving the Battered Woman Syndrome [BWS] defence. Through a rich and detailed study of trial transcripts from eleven cases of women, most of whom killed their battering partners, Sheehy demonstrates that the landmark Supreme Court of Canada decision in $R v$ Lavallée (discussed extensively in the first chapter) has not been as positive as feminists hoped it would be. Rather, Sheehy reveals that the application of the BWS defence is complicated, uneven and does not always reflect feminist objectives.

The book is organized into seven chapters. After a discussion of the case of Angelique Lyn Lavellée in chapter one, each subsequent chapter explores one or several similarly situated cases to consider the challenges and complications faced by women in their attempts to apply the law. Through her analysis, Sheehy demonstrates that the introduction of BWS as a self-defence strategy for battered women resulted in a mere shift in the form of law's sexism through increased facilitation of plea bargains for a lesser conviction of manslaughter, even in cases where going to trial may have led to acquittal. Thus, rather than justifying the woman's act due to required self-defence, the legal system instead takes pity on her through an acceptance of a lesser charge.

In chapter two, Sheehy examines the case of Bonnie Mooney to demonstrate that the disregard of police compounded with systemic barriers, including lack of job skills, fear of retaliation and shortage of space in women's centres, among other limitations, make it difficult for women to leave their abuser. By investigating the case of Kimberley Kondejewski, in chapter three, Sheehy illustrates how the mandatory life sentence for murder forms a barrier to women's access to justice. She rightly points out the significant impact of the actions and decisions of criminal justice actors, which can undermine legal changes and undercut battered women's ability to achieve justice through trial proceedings. The author's findings are in line with scholarship that investigates the way in which criminal justice actors contribute to the production of legal meaning and outcomes through their vast discretionary power. ${ }^{1}$ In chapters four and five, the author examines a number of cases to evaluate the effects of continued colonial violence against Aboriginal women in Canada and reveals how the law and the legal system enable this. Although the oppression of Aboriginal people by and through the legal system has previously been demonstrated by a number of scholars, ${ }^{2}$ Sheehy's work contributes valuable empirical support to this

\footnotetext{
PhD Candidate, Socio-Legal Studies, York University.

1 See Elzabeth Comack \& Gillian Balfour, The Power to Criminalize: Violence, Inequality and the Law (Halifax: Fernwood, 2004); Anne McGillivray \& Brenda Comaskey, Black Eyes All of the Time: Intimate Violence, Aboriginal Women and the Justice System (Toronto: University of Toronto Press, 1999); A Mountz, Seeking Asylum: Human Smuggling and Bureaucracy at the Border (Minneapolis: University of Minnesota Press, 2010); Anna Pratt, Securing Borders: Detention and Deportation in Canada (Vancouver: University of British Columbia Press, 2006).

2 See Sherene Razack,"Gendered Racial Violence and Spatialized Justice: The Murder of Pamela George," in Sherene Razack, ed, Race, Space and the Law: Unmapping a White Settler Society (Toronto: Between the Lines, 2002) 121; Sherene Razack, Looking White People in the Eye: Gender, Race, and Culture in Courtrooms and Classrooms (Toronto: Oxford University Press, 1998); Carmela Murdocca, "National Responsibility and Systemic Racism in Criminal
} 
scholarship. In chapters six and seven, she problematizes the use of BWS as a defence strategy for battered women who kill their partners. Sheehy illustrates that the specific requirements to prove the existence of BWS limit its application. ${ }^{3}$ She argues that the invocation of BWS necessarily requires the introduction of the psychiatric field and increases the possibility of a psychiatric label, ${ }^{4}$ which works to excuse women's actions "by reason of their psychological frailties or provocations", while failing to justify them based on self-defence." Through this kind of investigation of narrative constructions in battered women's trial proceedings, Sheehy contributes strong empirical evidence to the field of scholarship that aims to dismantle claims that the justice system and the law is impartial, just and equal. Given this rich empirical analysis of the difficulties battered women face at the hands of the criminal justice system, it comes as a surprise that Sheehy concludes with suggestions for law reform as a solution. For instance, the author's recommendations include legal changes, particularly to self-defence law, including the need to clarify the "excessive force" rule, which has led women to be disqualified from self-defence or plead guilty to manslaughter; and making self-defence available in case of first degree murder charges. ${ }^{6}$ As Sheehy's own detailed demonstration of the failures of legal changes resulting from Lavellee and the overwhelming documentation by a number of feminist scholars shows, ${ }^{7}$ legal changes alone cannot rectify gender specific issues such as 'wife battery' since legal logics, values and languages are nether neutral nor objective. This is particularly true for women who kill their battering partners as the violent and aggressive act extradites them from the category of the 'battered woman'. For these reasons and recognized failures in feminist attempts to use the law in the past, critical legal feminist scholarship has moved away from feminist jurisprudence.

Whether or not we believe that more law reform is the answer, this is an important book that provides insights into the operation of the self-defence law and the use of BWS for battered women who killed their abusive partners. Although the focus of the author's work is the use and interpretation of the law and legal strategies, she also demonstrates ways in which the law operates through ideological and discursive formations. Sheehy's straightforward explanation of the law, legal procedures and policies combined with a thorough explanation of the cases and contextualized in critical social science research makes the book an enjoyable and highly informative read not only for legal professionals, academics and students but also to those working with the issue on the front-lines.

Sentencing: The Case of R v Hamilton" in Law Commission of Canada, eds, The "Place" of Justice (Halifax: Fernwood, 2006) 67; McGillivray \& Comasky, supra note 1.

3 Elizabeth Sheehy, Defending Battered Women on Trial: Lessons from the Transcripts (Vancouver: University of British Columbia Press, 2014) at 233.

$4 \quad$ Ibid at 265.

5 Ibid at 232.

6 Ibid at 307-308.

7 Laureen Snider, "The Potential of the Criminal Justice System to Promote Feminist Concerns" (1990) 10 Studies in Law, Politics and Society 143; Carol Smart, Feminism and the Power of Law (London: Routledge, 1989); Carol Smart, Law, Crime and Sexuality: Essays in Feminism (London: Sage, 1995); Comack \& Balfour, supra note 1; Kevin Bonnycastle, "Rape Uncodified: Reconsidering Bill C-49 Amendments to Canadian Sexual Assault Law" in Dorothy Chunn \& Dany Lacombe, eds, Law as Gendering Practice (Toronto: Oxford University Press, 2000) 60. 